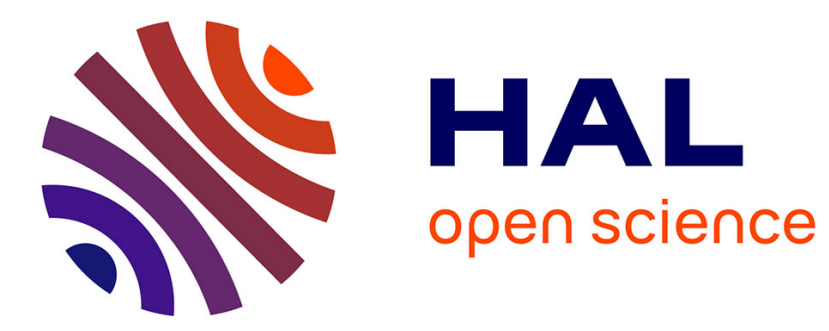

\title{
Geomagnetic paleosecular variation in the Brunhes period, from the island of El Hierro (Canary Islands)
}

Nadia Széréméta, Carlo Laj, Herve Guillou, Catherine Kissel, Alain Mazaud, Juan-Carlos Carracedo

\section{- To cite this version:}

Nadia Széréméta, Carlo Laj, Herve Guillou, Catherine Kissel, Alain Mazaud, et al.. Geomagnetic paleosecular variation in the Brunhes period, from the island of El Hierro (Canary Islands). Earth and Planetary Science Letters, 1999, 165 (3-4), pp.241-253. 10.1016/S0012-821X(98)00270-2 . hal03241830

\section{HAL Id: hal-03241830 \\ https://hal.science/hal-03241830}

Submitted on 31 May 2021

HAL is a multi-disciplinary open access archive for the deposit and dissemination of scientific research documents, whether they are published or not. The documents may come from teaching and research institutions in France or abroad, or from public or private research centers.
L'archive ouverte pluridisciplinaire HAL, est destinée au dépôt et à la diffusion de documents scientifiques de niveau recherche, publiés ou non, émanant des établissements d'enseignement et de recherche français ou étrangers, des laboratoires publics ou privés. 


\title{
Geomagnetic paleosecular variation in the Brunhes period, from the island of El Hierro (Canary Islands)
}

\author{
Nadia Széréméta ${ }^{\text {a }}$, Carlo Laj ${ }^{\text {a,* }}$, Hervé Guillou ${ }^{\text {a }}$, Catherine Kissel ${ }^{\text {a }}$, Alain Mazaud ${ }^{\text {a }}$, \\ Juan-Carlos Carracedo ${ }^{b}$ \\ ${ }^{a}$ Laboratoire des Sciences du Climat et de l'Environnement, CEA-CNRS, Avenue de la Terrasse, 91198 Gif-sur-Yvette cedex, France \\ ${ }^{b}$ Estacion Volcanologica de Canarias, CSIC, La Laguna, Tenerife, Spain
}

Received 6 June 1998; revised version received 20 November 1998; accepted 24 November 1998

\begin{abstract}
We have sampled a sequence of 69 flows in the island of El Hierro (Canary Islands). 46 of them belong to the El Golfo formation and 23 to the most recent rift formation. Radiometric dating brackets this section between 442 ka and $134 \mathrm{ka}$ with six intermediate datings. All the samples were stepwise demagnetized, partly with alternative field, partly thermally with very similar results. The large majority of the samples are characterized by a single stable component of magnetization. ChRM isolated after the first steps of demagnetization are all of normal polarity. Inclinations are on average shallower than expected from a geocentered dipole field, but consistent with results from other areas at the same latitude. Mean declinations of the rift and El Golfo sequences are both easterly deviated (about $5^{\circ}$ and $15^{\circ}$ respectively) and significantly different suggesting that the section has undergone a progressive clockwise rotation. VGP scatter and directional scatter calculated for the rift sequence are consistent with available data from other geographical areas, and also with recent models of paleosecular variation. On the other hand, a significantly smaller directional scatter is obtained for the lower El Golfo sequence, suggesting that a period of low secular variation occurred in the Canary Islands area between approximately 440 and 260 ka. (C) 1999 Elsevier Science B.V. All rights reserved.
\end{abstract}

Keywords: secular variations; magnetic field; absolute age; Canary Islands

\section{Introduction}

Records of the geomagnetic paleosecular variation provide crucial information for the understanding of the mechanisms generating the geomagnetic field. For this reason, numerous paleomagnetic investigations in the last three decades have addressed this question and have progressively contributed to a wide documentation of the paleosecular variation

\footnotetext{
* Corresponding author. Tel.: +33 (1) 6982 3538; Fax: +33 (1)
} 6982 3568; E-mail: laj@1sce.cnrs-gif.fr with increasing precision in time and geographical coverage. Despite this continuous effort, new data are still important, because the time-space coverage is as yet far from complete. For instance, in a recent publication, Johnson and Constable [1] indicate that available data do not allow unambiguous description of important characteristics of the field such as the Northern hemisphere flux lobes in the 0-5 Ma average field. Also, it has progressively appeared that some of the early data, obtained with methods that have been since superseded, may not be entirely reliable. For this reason, a recent IAGA 
resolution recommends that attention be given to repeating early studies on important sections using modern methods [2].

Despite the abundance of thick lava sequences with rather high extrusion rates, the Canary Islands have been relatively little studied from a paleomagnetic point of view. Early studies [3-7] were aimed toward understanding of tectonic evolution of the islands, rather than documenting the paleosecular variation. Consequently, of the over 350 data obtained from the Canary Island and Madeira, very few have been included in the data base used by Johnson and Constable [8] for the study of paleosecular variation. The most recent paleomagnetic studies in the Canary Islands have addressed the study of the MatuyamaBrunhes transition and the associated changes in the field intensity [9], not specifically paleosecular variation.

Recently, a combined K/Ar and magnetic polarity study of the Island of El Hierro [10], aiming for a better understanding of the island evolution, has also identified a Brunhes epoch volcanic sequence which appeared suitable for a paleosecular variation study with reliable age control. This provided the opportunity to obtain modern data from this rather poorly explored region.

\section{Geological setting and sampling}

El Hierro is the westernmost and smallest island $\left(280 \mathrm{~km}^{2}\right)$ of the Canary Islands (Fig. 1). It constitutes the emerging summit part of a volcanic edifice which lies over a $156 \mathrm{Myr}$ old seafloor at a depth of around $4000 \mathrm{~m}$. The island is thought to reflect the present location of the hotspot $[11,12]$. The eruptive activity seems to have been nearly continuous from $1.12 \mathrm{Ma}$ (oldest subaerial dated lava) to present, with the eruption of the Lomo Negro volcano in 1793 [13] possibly being the most recent event. Like many other volcanic islands, El Hierro is formed by the competition of consecutive constructive and destructive processes. Two main structural units succeeded in time: The oldest El Tiñor volcano was active during the upper part of the Matuyama Chron (between around 1.12 and $0.88 \mathrm{Ma}$ ) whereas the El Golfo edifice formed during the Brunhes period (between around 545 and $176 \mathrm{ka}$ ) [10]. The growth of instabil-

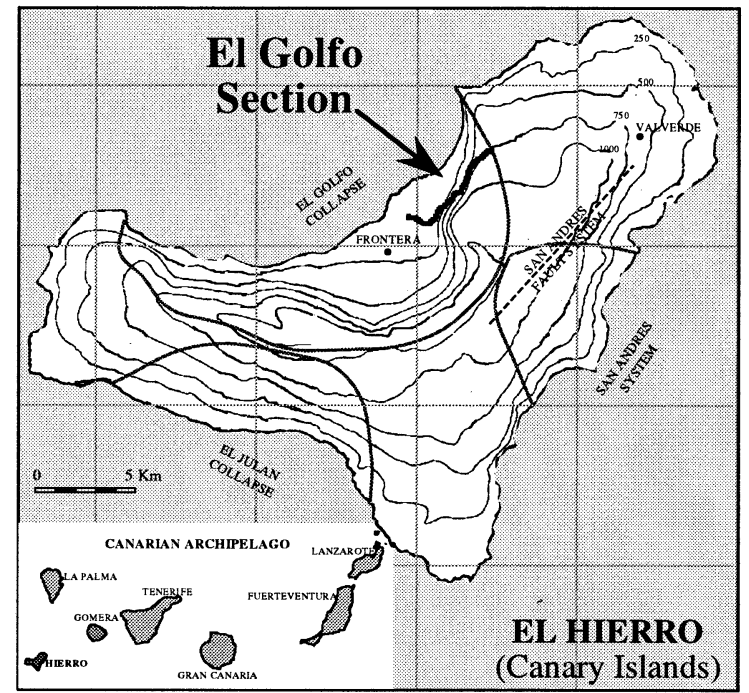

Fig. 1. Schematic map of El Hierro island indicating the location of the El Golfo section.

ities due to consecutive eruptions, perhaps coupled with magmatic overpressuring and pore fluid pressurization during dyke emplacements [14], has led to a number of volcano flank failures and consequent giant landslides with volumes of up to 1000 $\mathrm{km}^{3}$ [15-17]. During the youngest part of the Brunhes chron, a renewal of volcanic activity occurred through a well developed triple rift system building on top of the previous volcanic edifices of El Tiñor and El Golfo. Finally, the subsequent erosion of the landslides scars has resulted in the typical trilobate form of this island with its characteristic 'Mercedes star' rift system [17] associated with topological ridges at angles of $120^{\circ}$ (oriented in NW, NE and S) and large embayments especially in the south-west and north coasts (El Julan and El Golfo embayments respectively).

The sequence investigated in this study is located at the northern end of the El Golfo embayment, north of the town of Frontera, on the El Golfo volcanic edifice $\left(27.8^{\circ} \mathrm{N}, 18^{\circ} \mathrm{W}\right)$ (Fig. 1). Sampling extended along the Camino de la Peña from an altitude of $295 \mathrm{~m}$ up to the top of the section at about $700 \mathrm{~m}$ (Fig. 1) and encompassed the Upper El Golfo and the rift activity sequences. Below $295 \mathrm{~m}$, no paleomagnetic samples were collected because the section is covered by piedmont deposits densely intruded by dykes. 
The main part of the sampled section (the Upper El Golfo sequence between 300 and $620 \mathrm{~m}$ ) is made of thin to medium size basaltic flows progressively changing at the top to more differentiated (benmor-

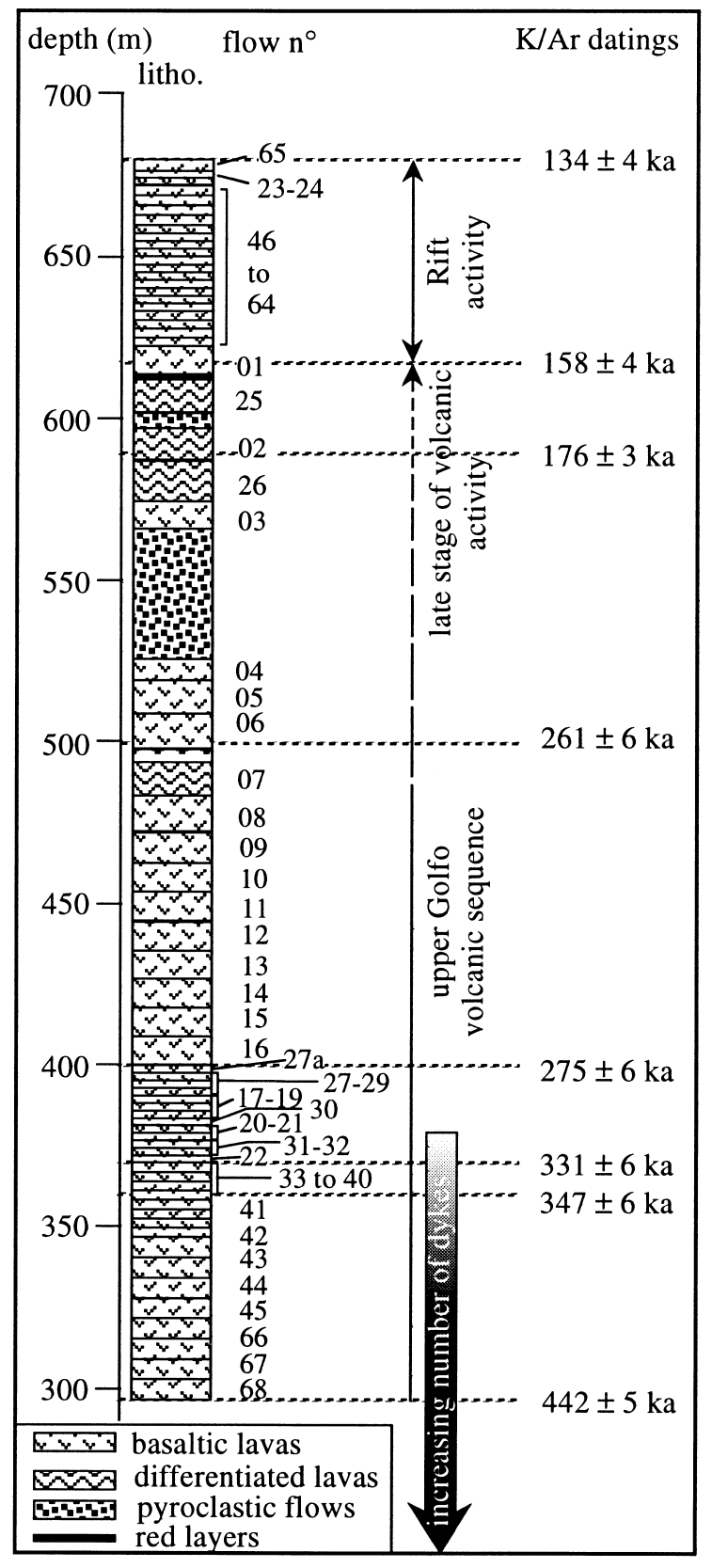

Fig. 2. Lithological description of the section as a function of altitude. $\mathrm{K}-\mathrm{Ar}$ datings are also reported. eites and trachytes) rather thick flows (Fig. 2). The very late stage of activity of the El Golfo volcano is characterized by very thick pyroclastic flows, not sampled for this study, illustrating a change from effusive towards explosive volcanic activity.

A well marked red soil located at the base of flow 01 separates the El Golfo sequence from the overlying recent rift sequence. This last sequence is constituted by an empilement of olivine and pyroxene bearing basaltic flows (flows EG01; EG23-24 and 46 to 65 ). The red soil illustrates that a time interval during which no lava flows were erupted or reached the investigated area is present between the two volcanic sequences.

The flows are usually unambiguously identified by the presence of basal and top scorias, ashes or red lapillus. We have sampled 69 flows which we believe to be consecutive, with the exception of two very thin flows which had obviously been reheated during the emplacement of overlying very thick flows and for this reason were not sampled. A total of 557 cores ( 7 to 10 cores per flow) were drilled with a portable gasoline-powered drill. For each flow, sampling extended laterally over several meters. From the almost 3-dimensional view offered by the geometry of the El Golfo embayment, it is clear that the general structure is periclinal and that the very shallow north-eastward dip of the El Golfo flows at the sampled section is of volcanic origin. Consequently, no correction was made to reconstruct the paleohorizontal. Each core was oriented in situ using, most often, both magnetic and sun compasses. Comparison of the solar and magnetic readings did not reveal any significant departure from the regional magnetic anomaly $\left(10^{\circ}\right.$ in 1980$)$ except for four isolated samples from two different flows. These samples were not considered for the measurements.

\section{Laboratory experiments and results}

\subsection{Radiometric datings}

Radiometric datings were obtained using an unspiked K/Ar technique which has already been described in the literature [18]. Prior to this paleomagnetic investigation, four age determinations had already been obtained at different horizons of the 
Table 1

Age determinations obtained from the El Golfo section

\begin{tabular}{|c|c|c|c|c|c|c|c|}
\hline Sample & $\begin{array}{l}\text { Height } \\
(\mathrm{m})\end{array}$ & $\begin{array}{l}\mathrm{K} \\
(\mathrm{wt} \%)\end{array}$ & $\begin{array}{l}\text { Weight molten } \\
(\mathrm{g})\end{array}$ & $\begin{array}{l}{ }^{40} \mathrm{Ar} \\
(\%)\end{array}$ & $\begin{array}{l}{ }^{40} \mathrm{Ar}^{\mathrm{a}}\left(\times 10^{-13}\right) \\
(\mathrm{moles} / \mathrm{g})\end{array}$ & $\begin{array}{l}\text { Age } \pm 2 \sigma \\
(\mathrm{ka})\end{array}$ & Mean age \\
\hline CI HI 40 & 680 & $0.665 \pm 0.007$ & 1.56447 & 1.620 & 1.521 & $132 \pm 6$ & \\
\hline CI HI 40 & 680 & $0.665 \pm 0.007$ & 2.01858 & 1.511 & 1.575 & $137 \pm 5$ & $134 \pm 4$ \\
\hline CI HI $01^{a}$ & 650 & $1.278 \pm 0.013$ & 1.43927 & 3.629 & 3.381 & $153 \pm 5$ & \\
\hline CI HI $01^{a}$ & 650 & $1.278 \pm 0.013$ & 2.4962 & 4.237 & 3.612 & $163 \pm 4$ & $158 \pm 4$ \\
\hline CI HI $02^{a}$ & 585 & $1.942 \pm 0.019$ & 2.51798 & 7.715 & 6.054 & $180 \pm 3$ & \\
\hline CI HI $02^{a}$ & 585 & $1.942 \pm 0.019$ & 2.50376 & 8.09 & 5.774 & $171 \pm 3$ & $176 \pm 3$ \\
\hline $\mathrm{CI} \mathrm{HI} 03^{\mathrm{a}}$ & 505 & $0.956 \pm 0.009$ & 1.50191 & 4.491 & 4.190 & $253 \pm 6$ & \\
\hline CI HI $03^{a}$ & 505 & $0.956 \pm 0.009$ & 2.51768 & 4.587 & 4.455 & $269 \pm 7$ & $261 \pm 6$ \\
\hline EG 16 & 400 & $0.819 \pm 0.008$ & 1.06324 & 1.824 & 3.975 & $280 \pm 10$ & \\
\hline EG 16 & 400 & $0.819 \pm 0.008$ & 1.33956 & 1.837 & 3.823 & $269 \pm 8$ & $275 \pm 6$ \\
\hline EG 22 & 370 & $0.843 \pm 0.008$ & 1.5258 & 1.995 & 4.888 & $333 \pm 7$ & \\
\hline EG 22 & 370 & $0.843 \pm 0.008$ & 1.09345 & 2.147 & 4.826 & $329 \pm 9$ & $331 \pm 6$ \\
\hline EG 40 & 360 & $0.502 \pm 0.005$ & 2.15037 & 1.693 & 3.000 & $349 \pm 8$ & \\
\hline EG 40 & 360 & $0.502 \pm 0.005$ & 1.94898 & 3.500 & 3.034 & $345 \pm 8$ & $347 \pm 6$ \\
\hline CI HI $04^{a}$ & 295 & $0.903 \pm 0.009$ & 1.49525 & 7.233 & 6.878 & $439 \pm 8$ & \\
\hline CI HI $04^{\mathrm{a}}$ & 295 & $0.903 \pm 0.009$ & 2.47259 & 7.294 & 6.957 & $444 \pm 8$ & $442 \pm 5$ \\
\hline
\end{tabular}

Age calculation are based on the decay and abundance constants from Steiger and Jäger [31].

a indicates determinations published in Ref. [10].

section [10]. Four additional determinations were obtained in this study, at altitudes $360,370,400$, and $680 \mathrm{~m}$, improving the temporal constraints for the lower part of the section. All the results are reported in Table 1. Two replicate measurements were done for each determination using different amounts of groundmass aliquots. This allows a direct check of the reproducibility of the laboratory measurements. Table 1 also shows that all the determinations are in stratigraphic order, providing evidence for the reliability of the results.

The section formed in an interval of about 300 kyr in the Brunhes period, between $442 \pm 5 \mathrm{ka}$ (295 $\mathrm{m})$ and $134 \pm 4 \mathrm{ka}(680 \mathrm{~m})$. The average extrusion rate in terms of flows per unit time, was calculated by linear interpolation between the different age determinations. In the lower part of the section (from EG68 to EG06) the sampled flows provide a rather regular sampling of the geomagnetic field, with spacings oscillating between 1.4, 4.3, $2.0 \mathrm{kyr}$ and close to $10.0 \mathrm{kyr}$ at the very bottom (an average value of 1 flow/4.5 kyr can be estimated). A sharp decrease of the extrusion rate is observed during the last stage of the El Golfo activity, when only 3 basaltic and 3 trachytic flows were emplaced between 261 and $158 \mathrm{ka}$. The extrusion rate then appears rather high (1 flow/1.1 kyr) for the rift activity sequence. It may be noted that, in terms of rate of production in volume of the volcanic products, there are no such corresponding large changes [10].

\subsection{Rock-magnetic analysis}

High field thermomagnetic analyses were made on small amounts of powder using a horizontal Curie balance. Heating and cooling rates were close to $7-8^{\circ} \mathrm{C} /$ minute and the maximum temperature approaching $700^{\circ} \mathrm{C}$. Argon was continuously flushed into the measuring cell to limit oxidation of the magnetic minerals during the experiments. In general, consistent results were observed for samples from the same flow, but some differences were observed along the section.

Concave-down curves decreasing to zero with Curie temperatures close to $580^{\circ} \mathrm{C}$ (Fig. 3a,b), characteristic of low Ti-content magnetites, were generally observed all along the sequence, although more frequently in the El Golfo than in the rift sequence. Curves such as that of Fig. 3c, with one inflection point in the interval of $350-450^{\circ} \mathrm{C}$, a second close to $580^{\circ} \mathrm{C}$, and a cooling curve above the heating curve, are abundant at the top of the section. Finally, curves such as the one in Fig. $3 \mathrm{~d}$ characterized by a decrease to zero with Curie temperatures in the 


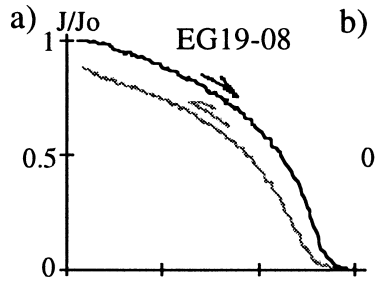

b) 1 J/Jo EG05-08

c)

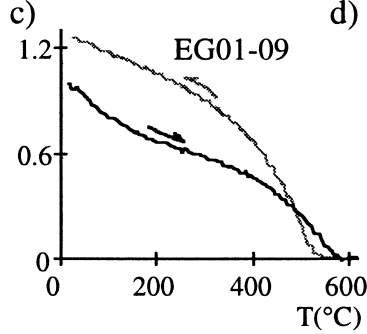

a)

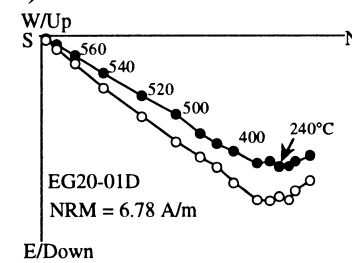

c)

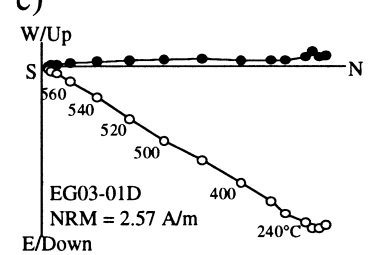

b)

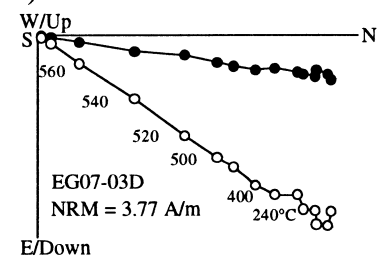

d)

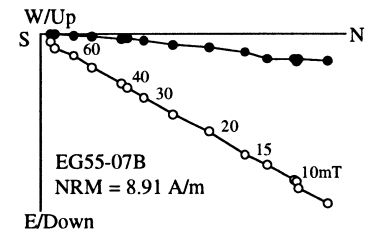

Fig. 3. Representative thermomagnetic analyses: (a-b) Similar shape for heating and cooling curves with a Curie temperature close to $580^{\circ} \mathrm{C}$ are mainly observed in the lower part of the section; (c-d) irreversible curves with 2 inflection points are mainly observed in the upper part of the section.

$250-350^{\circ} \mathrm{C}$ range and cooling curve high above the heating one, are also observed in the upper part of the section.

\subsection{Demagnetization of the NRM}

The remanent magnetization was measured either with a spinner magnetometer (JR5A) or with a 2G 3axes cryogenic magnetometer in a $\mu$-metal shielded room. NRMs range between 0.3 and $34 \mathrm{~A} / \mathrm{m}$ with a mean value of $7.9 \mathrm{~A} / \mathrm{m}$. Samples from the same flow have very similar NRMs, illustrating intra-flow homogeneity. Stepwise thermal (th) and alternative field (af) demagnetization performed on samples of the same core yielded very similar Characteristic Remanent Magnetizations (ChRM). On average, 45 samples per flow were treated thermally up to $600^{\circ} \mathrm{C}$ and the others underwent af demagnetization up to $0.1 \mathrm{~T}$. The steps of the thermal treatment were usually chosen considering the results of the thermomagnetic analysis. The low field magnetic susceptibility was measured at room temperature after each step of the thermal treatment in order to detect possible heating-induced mineralogical changes. The consistency between the directions obtained from af and thermal demagnetization ensures that the mineralogical transformations documented in some sam-

Fig. 4. Typical thermal (a, b, c) and af (d) demagnetization diagrams. White and black symbols are for projection onto vertical and horizontal planes respectively.

ples by the thermomagnetic analyses do not significantly affect the determination of their ChRM. However, for some of the samples characterized by thermomagnetic curves such as that of Fig. $3 d$, the thermal treatment yielded slightly 'noisier' diagrams with Maximum Angle of Deviation (MAD) values of about $4-5^{\circ}$. In these cases af demagnetization yielded more accurate and consistent determinations of the ChRM with MAD values of $1-2^{\circ}$.

A great majority of samples are characterized by a single stable component of magnetization, sometimes associated with a small secondary component easily removed after the first demagnetization steps (i.e. $180-240^{\circ} \mathrm{C}$ or $10-15 \mathrm{mT}$ ). Characteristic examples of demagnetization diagrams are shown in Fig. 4. Principal component analysis was used to determine direction of the ChRM for each sample. Using a Fisher statistic, the mean paleofield direction for each flow was then obtained with an average $\alpha_{95}$ of $4.6^{\circ}$.

\subsection{The paleomagnetic record}

The paleomagnetic results are reported in Table 2 part a, with the usual Fisher statistical parameters. These results are shown in Fig. 5a as inclination/declination records as a function of flow number in the stratigraphic order, and in Fig. $5 \mathrm{~b}$ as a function of time, where the age assigned to each flow 
Table 2

Paleomagnetic results from the El Golfo section

\begin{tabular}{|c|c|c|c|c|c|c|c|c|c|c|c|c|}
\hline \multicolumn{8}{|l|}{ Part a } & \multicolumn{5}{|c|}{ Part b } \\
\hline Flow No. & Dec & Inc & $N$ & $K$ & $\alpha_{95}$ & Lat & Long & $\operatorname{Dec}^{\prime}$ & Inc $^{\prime}$ & $N^{\prime}$ & $K^{\prime}$ & $\alpha_{95}^{\prime}$ \\
\hline 65 & 342.9 & 57.3 & 7 & 129.4 & 4.9 & 72.5 & -68.2 & & & & & \\
\hline 23 & 335.8 & 59.8 & 9 & 114.2 & 4.6 & 66.2 & -68.8 & & & & & \\
\hline 24 & 333.9 & 59.4 & 5 & 274.8 & 4.1 & 65.2 & -71.2 & 337.8 & 59.0 & 21 & 153.8 & 2.6 \\
\hline 46 & 8.7 & 38.5 & 6 & 218.3 & 4.1 & 80 & 107.7 & 8.7 & 38.5 & 6 & 218.3 & 4.1 \\
\hline 47 & 0.3 & 41.2 & 5 & 340.6 & 3.7 & 85.9 & 158.2 & 0.3 & 41.2 & 5 & 340.6 & 3.7 \\
\hline 48 & 11.1 & 35.3 & 5 & 478.9 & 3.6 & 76.9 & 108.8 & 11.1 & 35.3 & 5 & 478.9 & 3.6 \\
\hline 49 & 8.2 & 39.7 & 2 & - & - & 80.9 & 105.8 & & & & & \\
\hline 50 & 8.4 & 40.3 & 7 & 427 & 2.7 & 81 & 102.6 & 8.3 & 40.2 & 9 & 366.0 & 2.5 \\
\hline 51 & 0.4 & 28.4 & 8 & 97.2 & 5.3 & 77.3 & 160.1 & 0.4 & 28.4 & 8 & 97.2 & 5.3 \\
\hline 52 & 21.2 & 26.2 & 7 & 142.6 & 5.3 & 65.8 & 103 & 21.2 & 26.2 & 7 & 142.6 & 5.3 \\
\hline 53 & 352.6 & 21.8 & 5 & 483.6 & 3.1 & 72.1 & -173.6 & & & & & \\
\hline 54 & 353.7 & 21.7 & 9 & 99 & 4.9 & 72.5 & -177.2 & 353.3 & 21.7 & 14 & 153.3 & 3.1 \\
\hline 55 & 359.8 & 37 & 6 & 188.6 & 4.5 & 82.8 & 163.3 & 359.8 & 37 & 6 & 188.6 & 4.5 \\
\hline 56 & 12.5 & 40 & 5 & 624.1 & 2.7 & 77.7 & 93.3 & 12.5 & 40 & 5 & 624.1 & 2.7 \\
\hline 57 & 19.5 & 47.2 & 9 & 74.4 & 5.7 & 72.8 & 65.6 & 19.5 & 47.2 & 9 & 74.4 & 5.7 \\
\hline 58 & 359.9 & 39.8 & 6 & 394.9 & 3.1 & 84.8 & 162.8 & 359.9 & 39.8 & 6 & 394.9 & 3.1 \\
\hline 59 & 14.1 & 19.8 & 7 & 128.2 & 5 & 68 & 122.3 & 14.1 & 19.8 & 7 & 128.2 & 5 \\
\hline 60 & 13.3 & 25.2 & 8 & 123.3 & 4.7 & 70.9 & 118.8 & & & & & \\
\hline 61 & 16.9 & 27 & 6 & 738.2 & 2.5 & 69.3 & 109.3 & 15.0 & 24.9 & 14 & 124.7 & 3.3 \\
\hline 62 & 359.8 & 35.8 & 7 & 36.7 & 10.7 & 82.9 & -163.4 & & & & & \\
\hline 63 & 348.7 & 35.7 & 9 & 143.2 & 4.3 & 76.9 & -143.4 & 353.5 & 35.9 & 16 & 56.1 & 5.0 \\
\hline 64 & 20.1 & 24 & 4 & 80.3 & 10.3 & 65.8 & 107 & 20.1 & 24 & 4 & 80.3 & 10.3 \\
\hline 1 & 26.1 & 42 & 6 & 85.6 & 7.3 & 66.3 & 134.7 & 26.1 & 42 & 6 & 85.6 & 7.3 \\
\hline 25 & 349.5 & 40.9 & 6 & 67.4 & 8.2 & 79.6 & -70.5 & & & & & \\
\hline 2 & 352.6 & 35.4 & 8 & 182.1 & 4.1 & 79.3 & -156.9 & & & & & \\
\hline 26 & 349 & 36.8 & 8 & 233.1 & 3.6 & 77.6 & -141.7 & & & & & \\
\hline 3 & 353.3 & 39.1 & 9 & 190.3 & 3.8 & 81.7 & -89.6 & 351.6 & 37.8 & 31 & 130.9 & 2.4 \\
\hline 4 & 1.7 & 31.9 & 9 & 249.5 & 3.3 & 79.4 & 159.1 & & & & & \\
\hline 5 & 356.5 & 30 & 8 & 139.5 & 4.7 & 77.9 & 178.4 & 359.2 & 31.0 & 17 & 161.2 & 2.8 \\
\hline 6 & 1.8 & 24 & 8 & 296.3 & 3.2 & 74.7 & 155.4 & 1.8 & 24 & 8 & 296.3 & 3.2 \\
\hline 7 & 9.7 & 31.4 & 7 & 624.5 & 2.4 & 75.9 & 120.3 & 9.7 & 31.4 & 7 & 624.5 & 2.4 \\
\hline 8 & 3.2 & 43.9 & 6 & 290.2 & 3.6 & 86.5 & 107.8 & 3.2 & 43.9 & 6 & 290.2 & 3.6 \\
\hline 9 & 16.3 & 25.4 & 4 & 175.5 & 6 & 70.9 & 105.7 & & & & & \\
\hline 10 & 13.4 & 29.2 & 7 & 278.6 & 3.4 & 72.6 & 113.8 & 14.5 & 27.8 & 11 & 229.8 & 2.9 \\
\hline 11 & 14 & 36 & 7 & 137.3 & 4.8 & 75 & 100.4 & & & & & \\
\hline 12 & 13.6 & 28.2 & 8 & 128.4 & 4.6 & 72 & 114.5 & & & & & \\
\hline 13 & 10.8 & 28.7 & 8 & 178.8 & 3.9 & 74 & 121.2 & 12.2 & 28.4 & 16 & 178.0 & 2.8 \\
\hline 14 & 4.4 & 48.3 & 7 & 96.6 & 5.7 & 85.9 & 49.2 & & & & & \\
\hline 15 & 9.9 & 50.3 & 8 & 181.1 & 3.9 & 80.8 & 49.2 & 7.2 & 49.3 & 15 & 134.0 & 3.2 \\
\hline 16 & 23.8 & 39.7 & 7 & 103.3 & 5.5 & 67.8 & 80.3 & 23.8 & 39.7 & 7 & 103.3 & 5.5 \\
\hline $27 \mathrm{a}$ & 10.5 & 41.7 & 4 & 203 & 5.6 & 79.8 & 91.4 & 10.5 & 41.7 & 4 & 203 & 5.6 \\
\hline 27 & 32.5 & 41.4 & 10 & 211.9 & 3.2 & 60.6 & 72.3 & 32.5 & 41.4 & 10 & 211.9 & 3.2 \\
\hline 28 & 23.9 & 36.3 & 6 & 212.2 & 4.2 & 66.8 & 86 & 23.9 & 36.3 & 6 & 212.2 & 4.2 \\
\hline 29 & 16.8 & 37.5 & 7 & 228.6 & 3.7 & 73.3 & 92.2 & 16.8 & 37.5 & 7 & 228.6 & 3.7 \\
\hline 17 & 24.3 & 35.6 & 6 & 144.6 & 5.1 & 66.3 & 86.8 & 24.3 & 35.6 & 6 & 144.6 & 5.1 \\
\hline 18 & 16 & 30.3 & 7 & 153.6 & 4.5 & 71.3 & 106.6 & 16 & 30.3 & 7 & 153.6 & 4.5 \\
\hline 19 & 19.9 & 39.3 & 6 & 83.8 & 6.7 & 71.1 & 84.7 & & & & & \\
\hline 30 & 15.9 & 37.1 & 8 & 299.1 & 3 & 73.9 & 94.5 & 17.5 & 37.9 & 14 & 150.7 & 3.1 \\
\hline 20 & 27 & 36.4 & 6 & 108.3 & 5.9 & 64.3 & 83.2 & 27 & 36.4 & 6 & 108.3 & 5.9 \\
\hline 21 & 12.3 & 35.2 & 7 & 127.7 & 5 & 76 & 106.1 & 12.3 & 35.2 & 7 & 127.7 & 5 \\
\hline 31 & 24.8 & 38.1 & 12 & 122 & 3.8 & 66.6 & 82.3 & & & & & \\
\hline 32 & 22.6 & 36.8 & 7 & 143 & 4.7 & 68.2 & 86.5 & 23.7 & 37.7 & 19 & 145.0 & 2.8 \\
\hline
\end{tabular}


Table 2 (continued)

\begin{tabular}{|c|c|c|c|c|c|c|c|c|c|c|c|c|}
\hline \multicolumn{8}{|l|}{ Part a } & \multicolumn{5}{|l|}{ Part b } \\
\hline Flow No. & Dec & Inc & $N$ & $K$ & $\alpha_{95}$ & Lat & Long & $\operatorname{Dec}^{\prime}$ & $\mathrm{Inc}^{\prime}$ & $N^{\prime}$ & $K^{\prime}$ & $\alpha_{95}^{\prime}$ \\
\hline 22 & 9 & 40.9 & 11 & 98.8 & 4.4 & 80.8 & 98.7 & & & & & \\
\hline 33 & 17.7 & 41 & 7 & 130.6 & 4.9 & 73.5 & 83.2 & 12.5 & 41.1 & 18 & 109.7 & 3.3 \\
\hline 34 & 16.1 & 45.5 & 5 & 253.1 & 4.3 & 75.7 & 71.5 & & & & & \\
\hline 35 & 13.5 & 47.7 & 7 & 259.2 & 3.5 & 78.1 & 64.2 & & & & & \\
\hline 36 & 9.3 & 45.4 & 6 & 307.2 & 3.5 & 81.7 & 76.2 & 12.8 & 46.1 & 18 & 266.9 & 2.1 \\
\hline 37 & 5.5 & 47 & 8 & 90.8 & 5.5 & 85.1 & 65.9 & & & & & \\
\hline 38 & 0.1 & 45.3 & 7 & 127.2 & 5 & 89 & 156.5 & & & & & \\
\hline 39 & 4.8 & 42.7 & 8 & 94.8 & 5.3 & 84.8 & 106.4 & & & & & \\
\hline 40 & 3.5 & 42.7 & 9 & 136.7 & 4.2 & 85.6 & 115.3 & 3.7 & 44.3 & 32 & 127.5 & 2.3 \\
\hline 41 & 11.3 & 39.7 & 9 & 201.4 & 3.4 & 78.5 & 96.8 & & & & & \\
\hline 42 & 11 & 35.4 & 8 & 169 & 4 & 77 & 109 & & & & & \\
\hline 43 & 13.7 & 36.8 & 8 & 173.4 & 3.9 & 75.5 & 99.4 & 11.0 & 37.4 & 25 & 160.0 & 2.3 \\
\hline 44 & 5.3 & 43.2 & 5 & 340 & 3.7 & 84.6 & 99.6 & 5.3 & 43.2 & 5 & 340 & 3.7 \\
\hline 45 & 16.9 & 41.2 & 7 & 92.4 & 5.8 & 74.2 & 83.5 & 16.9 & 41.2 & 7 & 92.4 & 5.8 \\
\hline 66 & 27.9 & 32.6 & 8 & 165.1 & 4 & 62.4 & 87.4 & 27.9 & 32.6 & 8 & 165.1 & 4 \\
\hline 67 & 13.9 & 38.8 & 5 & 118.2 & 6.3 & 76.1 & 94.1 & & & & & \\
\hline 68 & 16.4 & 38 & 6 & 119.5 & 5.6 & 73.8 & 91.7 & 15.0 & 38.5 & 11 & 153.9 & 3.5 \\
\hline
\end{tabular}

Part a: unfiltered data. Part b: filtered data. $N, N^{\prime}$ : Number of stable directions used for statistical calculation. $K, K^{\prime}, \alpha_{95}, \alpha_{95}^{\prime}:$ parameters of Fisher's statistics.

was obtained by linear interpolation between the intermediate radiometric datings as reported above. The marked decrease of the extrusion rate at the end of the El Golfo activity is clearly apparent from Fig. 5b. Consequently the interpolated age for the six undated flows in the interval 261 to $158 \mathrm{kyr}$ is highly speculative (one of the flows in this interval is dated).

As expected from the datings, only normal polarities were observed in this record, but the average paleomagnetic directions calculated separately for the El Golfo and rift sequences are significantly different. For the rift (r) sequence, this direction is defined by: $\mathrm{Nr}=23, \mathrm{Dr}=5.1^{\circ}, \mathrm{Ir}=37.3^{\circ}, \mathrm{Kr}=$ 26.9, $\alpha_{95} \mathrm{r}=5.9^{\circ}$, and for El Golfo (eg) sequence by: $\mathrm{Neg}=40, \mathrm{Deg}=14.2^{\circ}$, Ieg $=38.6^{\circ}, \mathrm{Keg}=87.8$, $\alpha_{95} \mathrm{eg}=2.43^{\circ}$. In calculating this last direction the 6 flows corresponding to the very late stage of the El Golfo sequence were not considered (see discussion below).

The average inclinations do not significantly differ between the two sequences, and both are shallower than expected from a geocentred axial dipole (the average inclination anomaly calculated for the entire section is $\left.\Delta I=-8.5^{\circ}\right)$. On the other hand, the average declinations calculated for the two se- quences are both different from zero and different from each other. For the rift sequence, the mean declination is $\operatorname{Dr}=5.1 \pm 7.5^{\circ}$, and for the El Golfo sequence Deg $=14.2 \pm 3.1^{\circ}$. A statistical test [19] shows that these two directions are significantly different at the $99 \%$ confidence level.

\section{Discussion}

\subsection{Serial correlation between flows}

Volcanic series provide accurate spot readings of the past geomagnetic field, allowing investigation of the secular and millennial variability of the geodynamo. However, because of the erratic nature of volcanic emission, it may happen that a large number of flows are emitted in such a rapid succession that they all record the same direction of the geomagnetic field. If ignored, this serial correlation may lead to incorrect estimates of the dispersion of the field directions. It is unfortunately not so simple to address this issue, and rather contrasting views have been held by different authors.

On the one hand, some investigators have attempted to detect possible data redundancy by group- 


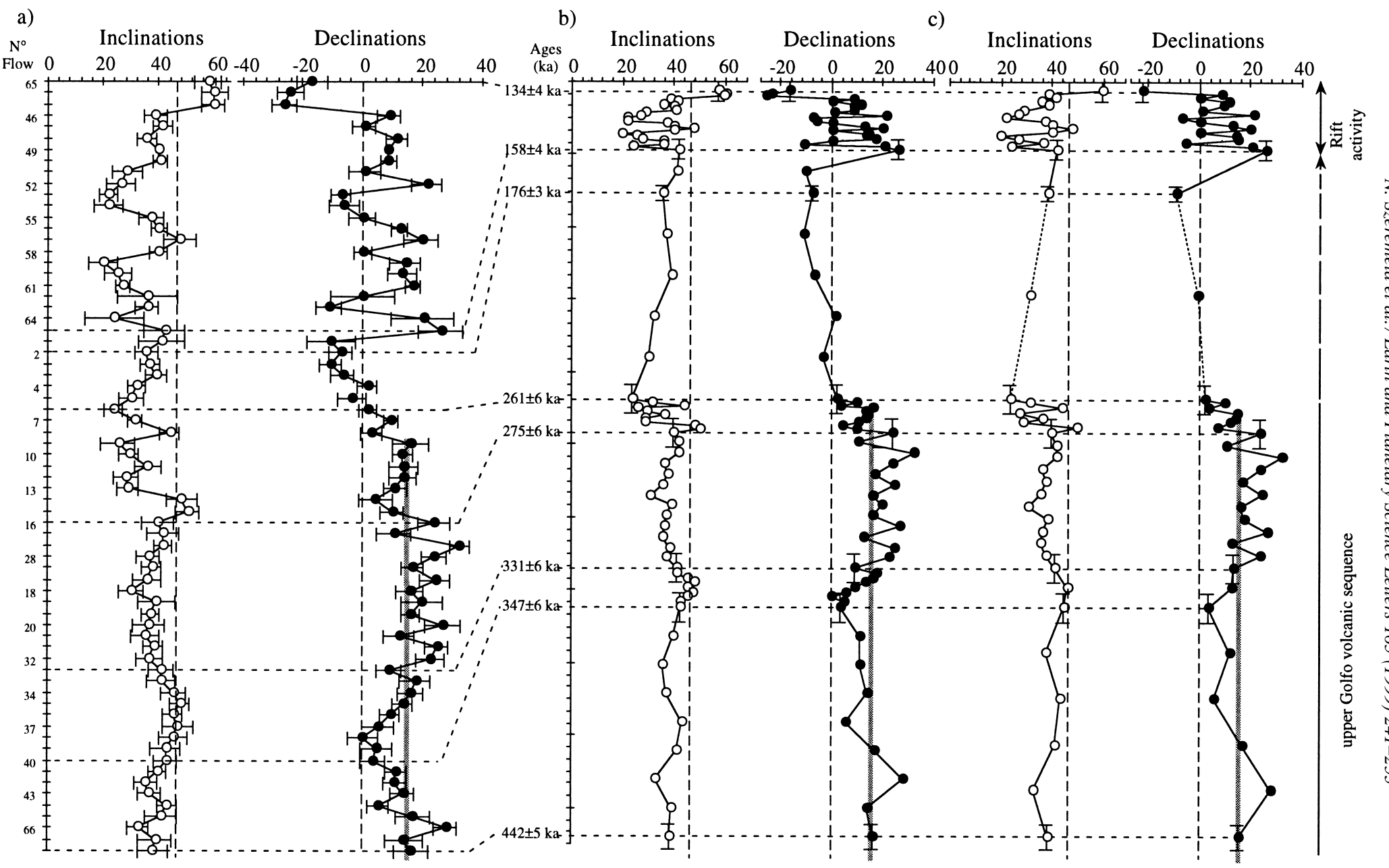

Fig. 5. Inclination and declination records as a function of (a) flow numbers reported in the stratigraphic order (b) interpolated ages. (c) is the same as (b) for filtered data. In (c) no realistic age interpolation can be inferred for the interval between 261 and $176 \mathrm{ka}$ (see text) as illustrated by the dotted line. In the 3 plots, the dashed vertical lines indicate the inclination and declination values expected for a geocentred axial dipole field, and the grey vertical lines reported for the El Golfo sequence illustrate the mean declination deduced from the data. 
ing into 'directional groups' consecutive directions which appear to be repetitive sampling of the same geomagnetic field vector. Mankinen et al. [20], for instance, directly examined whether or not the $95 \%$ confidence ovals of successive flow directions overlapped, to infer possible serial correlation. More recently, McElhinny et al. [21] and Vandamme and Bruneton [22] used a critical value for the angular difference between the paleomagnetic vectors of two successive flows, in order to decide whether the two flows recorded independent readings of the geomagnetic field. The two methods differ in the way the critical angle is calculated. In the McElhinny et al. [21] method, the critical angle is an average over the entire section, whereas it depends specifically on the two flows whose correlation is being tested in the second approach.

On the other hand, Love [23] argued that combining data using only directional criteria may lead to incorrect conclusions, because the rate of secular variation may itself be strongly variable. Consequently, similar paleomagnetic directions may be due to true field behavior. In addition, Love noted that field intensity may vary substantially in the absence of significant directional changes, as indicated by historical geomagnetic variations.

Given these strongly different views, we have taken the conservative approach of considering filtered and unfiltered data, in order to assess the impact of filtering on the interpretation of the results. We have used the filtering method of Vandamme and Bruneton [22]. In addition, the test was repeated for each pair of flows within each cluster composed of 3 or more flows. This procedure avoided grouping together flows having recorded slow geomagnetic directional trends (such as that observed between flows EG22 to 40) into a single large cluster. The method was applied to the El Golfo and rift sequences separately, because the red soil provides evidence for a significant break in the extrusion rate.

The results are shown in Table 2 (part b) in which the flows yielding similar directions are identified as alternating white and light grey rows, while Fig. 5c shows the filtered directional record versus interpolated ages. It can be seen that for both the rift sequence and the El Golfo sequence below $261 \mathrm{ka}$, filtering does not drastically affect the characteristics of the record obtained from unfiltered data. For in- stance, the average paleomagnetic directions for the two sequences before and after filtering differ by only $2.7^{\circ}$ (rift sequence) and $1.2^{\circ}$ (El Golfo).

On the other hand, filtering has a rather strong effect in the interval 261 to $158 \mathrm{ka}$ : the three trachytic flows and the three basaltic flows are grouped in two directional clusters, and it is not possible to infer a realistic age interpolation for them. For this reason, we have decided not to consider these flows in the discussion of the results. Our analysis is restricted to the rift sequence and to the El Golfo sequence below $261 \mathrm{ka}$.

\subsection{The inclination/declination record}

As reported above, inclinations from the two sequences are quite consistent and are shallower than expected from a geocentered dipole field. This characteristics of the field has been observed in many previous studies from geographically widespread sites (Wilson's off-centered dipole effect, see Johnson and Constable [8] for references). It results in VGPs lying beyond the geographic pole (Fig. 6a), far-sided with respect to the sampling location. The average inclination anomaly observed at El Hierro $\left(-8.5^{\circ}\right)$ is slightly higher than values reported from other studies in the Canary Islands [7]. It is, however, consistent with values obtained from sites in the same latitudinal band over the past 5 Myr [1] (Fig. 7).

The average declinations of the rift and El Golfo sequences are both easterly deviated and significantly different. For the rift sequence, which has lasted only $\sim 25 \mathrm{kyr}$, one may eventually consider that an episode of secular variation with non zero declination has occurred. It is more difficult to consider a geomagnetic origin for the non zero declinations of the El Golfo sequence because they were systematically easterly deviated by an angle of $\sim 15^{\circ}$ for over $100 \mathrm{kyr}$, an interval of time longer than the time constants involved in geomagnetic secular variation. In our opinion, the most realistic hypothesis which properly accounts for this feature is that the section has undergone a clockwise rotation. The smaller declination observed for the rift sequence would then suggest that part of the rotation has occurred recently, after fissural activity. As no other coeval paleomagnetic results are available from El 

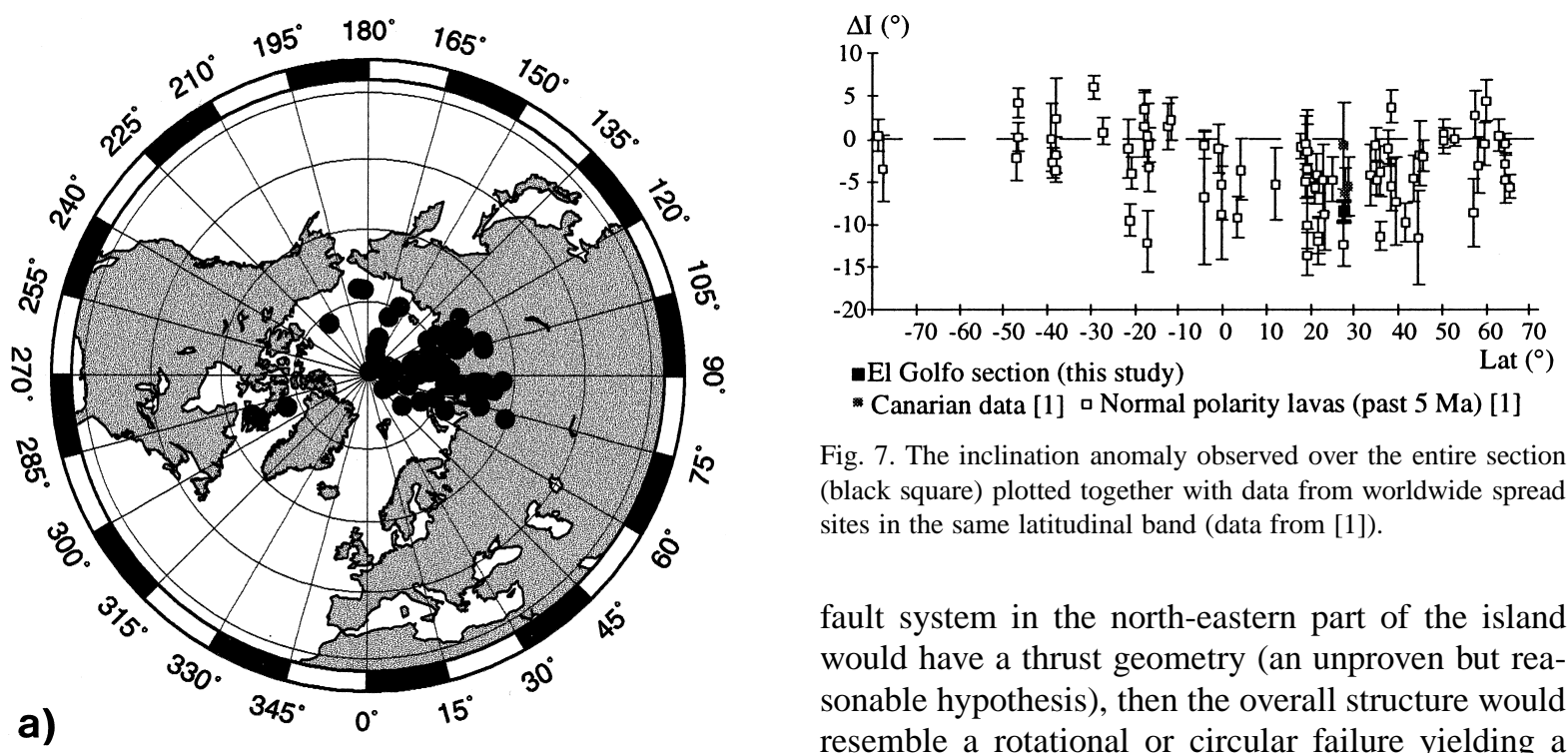

Fig. 7. The inclination anomaly observed over the entire section (black square) plotted together with data from worldwide spread sites in the same latitudinal band (data from [1]).

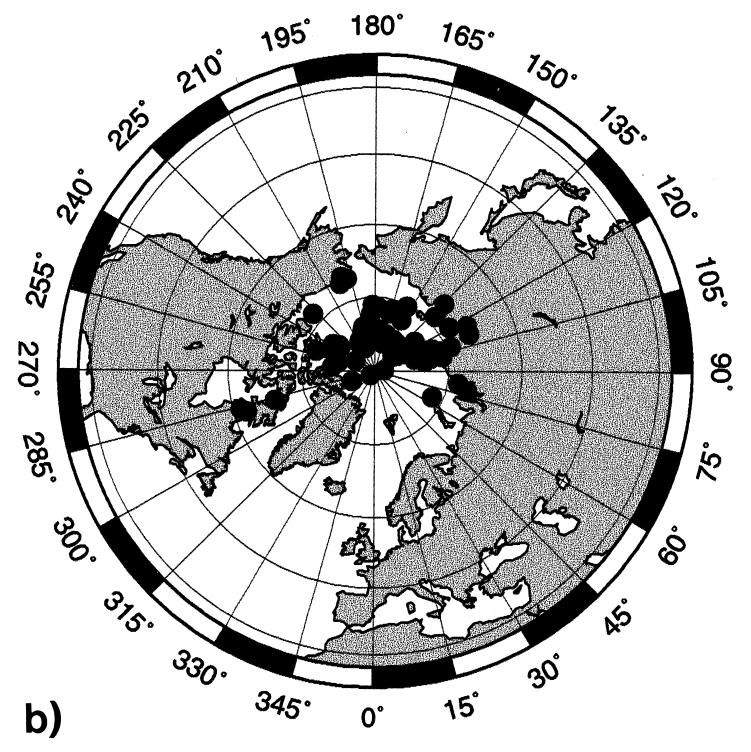

Fig. 6. Stereographic projection of the VGPs obtained for the rift and El Golfo sequences, using data (a) uncorrected and (b) after applying a counterclockwise rotation on the declination record $\left(5.1^{\circ}\right.$ for the rift sequence and $14.2^{\circ}$ for the El Golfo sequence).

Hierro, we have no evidence to discriminate between a rotation of the entire island and a local block rotation. This last hypothesis would be consistent with the known structural framework of the island. Indeed, it has been suggested by Day et al. [24] that if the downslope submerged part of the San Andrès fault system in the north-eastern part of the island would have a thrust geometry (an unproven but reasonable hypothesis), then the overall structure would resemble a rotational or circular failure yielding a clockwise rotation. Depending on the relative orientation of the fault and the paleomagnetic direction this would not necessarily affect inclination values. Only future paleomagnetic investigation will allow to discriminate between the two scenarios. Whatever the mechanisms of this rotation, in the following discussion we have counterclockwise rotated the declinations of the two sequences, by $5.1^{\circ}$ for the rift and $14.2^{\circ}$ for El Golfo sequences, in order to have zero average declination in both cases. However, we have pointed out what the major differences would be, if this rotation had not been considered. The effect of this correction on the VGP distribution is shown in Fig. 6 b.

\subsection{The scatter of the paleomagnetic directions}

To evaluate the amplitude of the secular variation we have first calculated the scatter of the VGPs about the geographic pole, following McElhinny and McFadden [25]. The geomagnetic VGP dispersion $S_{\mathrm{f}}$ (corrected for the within-site dispersion) was calculated with lower $\left(S_{1}\right)$ and upper $\left(S_{\mathrm{u}}\right) 95 \%$ confidence limits following Cox [26]. The results for the rift and El Golfo sequences are shown in Table 3, where all possible cases are considered (filtered and non filtered data, data corrected for the rotation or not). It can be seen that for the two sequences, filtering has a non significant effect on the amplitude of the VGP scatter, which is only slightly reduced by about 
Table 3

VGP scatters calculated for the El Golfo section

\begin{tabular}{lllllll}
\hline & & \multicolumn{2}{l}{ Unrotated data } & & \multicolumn{2}{c}{ Rotated data } \\
\cline { 3 - 4 } \cline { 6 - 7 } & & $\begin{array}{l}\text { Raw } \\
\text { data }\end{array}$ & $\begin{array}{l}\text { Filtered } \\
\text { data }\end{array}$ & & $\begin{array}{l}\text { Raw } \\
\text { data }\end{array}$ & $\begin{array}{l}\text { Filtered } \\
\text { data }\end{array}$ \\
\hline \multirow{2}{*}{ Rift } & $S_{\mathrm{f}}$ & 17.2 & 16.8 & & 16.8 & 15.2 \\
& $S_{\mathrm{l}}$ & 14.3 & 13.6 & & 13.9 & 12.3 \\
& $S_{\mathrm{u}}$ & 21.8 & 21.6 & & 21.2 & 19.6 \\
& $S_{\mathrm{f}}$ Golfo & 16.3 & 17.6 & & 9.8 & 10.5 \\
& $S_{\mathrm{l}}$ & 14.1 & 14.8 & & 8.5 & 8.8 \\
& $S_{\mathrm{u}}$ & 19.3 & 21.8 & & 11.6 & 13.0 \\
\hline
\end{tabular}

$S_{\mathrm{f}}$ is the VGP scatter calculated with respect to the spin axis and corrected for the within-site dispersion [25]. $S_{1}$ and $S_{\mathrm{u}}$ are lower and upper $95 \%$ confidence limits [26].

$1-2^{\circ}$ when filtered data are considered, with respect to unfiltered data.

Correcting for the rotation of the section has a limited impact on the results from the rift sequence, as expected from the fact that the correction for the rotation in this case is only $5^{\circ}$. Both before and after correction for the rotation and for both filtered and unfiltered data, the scatter of the VGPs is slightly higher than the predictions of Model G of McElhinny and McFadden [25], but consistent with this model within the accuracy limits (Fig. 8a). It may be noted that data from worldwide spread sites in the same latitudinal band also document VGPs scatter somewhat larger than predicted from this model.

On the other hand, the value of the VGPs scatter obtained from the El Golfo sequence decreases significantly (from $\sim 17^{\circ}$ to $\sim 10^{\circ}$ ) upon correction for the rotation. While the uncorrected value would be consistent with model $\mathrm{G}$, the corrected value is significantly smaller than that predicted by the model (Fig. 8b). This small scatter would suggest that a period of reduced amplitude of the secular variation has occurred in the region of the Canary islands in the period from 442 to $261 \mathrm{ka}$.

The suggestion of reduced secular variation, deduced from the low VGP scatter, is entirely dependent on whether the data are corrected for the rotation of the island or not. Although, in our opinion, a rotation of the island is the most realistic explanation for the easterly seeking declinations, we have investigated this point further, by examining the
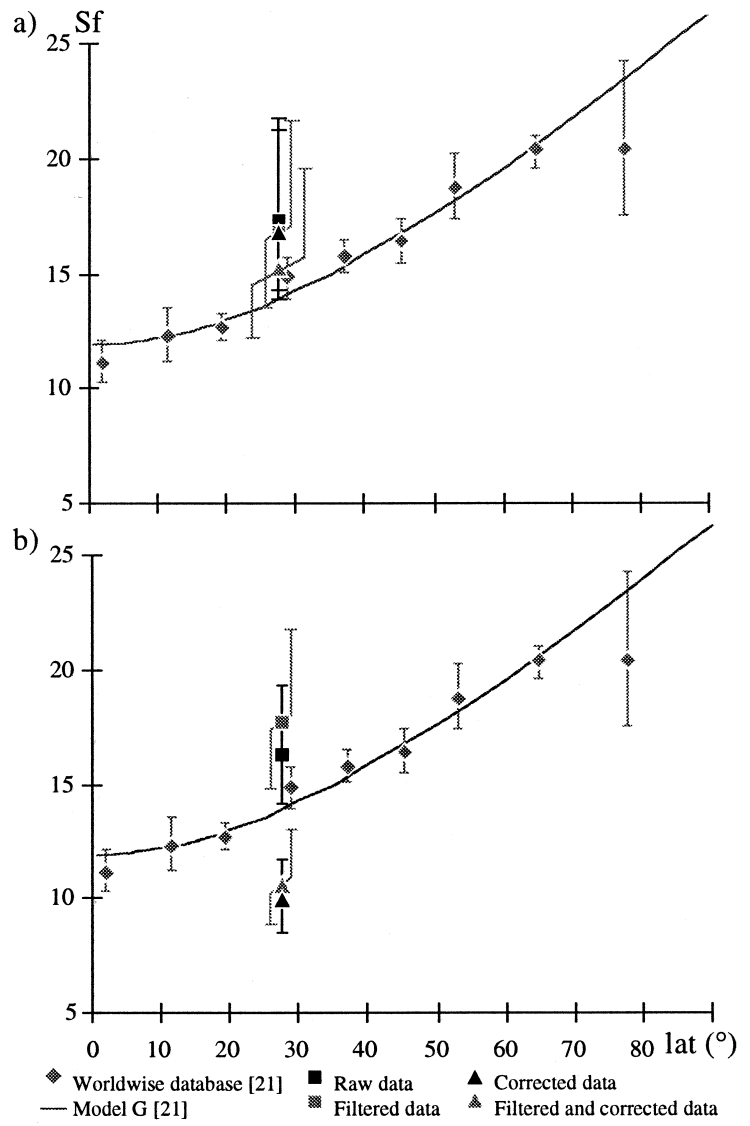

Fig. 8. VGP scatter, with respect to the spin-axis and corrected for the within-site dispersion, reported as a function of latitude, together with McElhinny and McFadden world-wide database and model $\mathrm{G}$ (from [25]). $S_{\mathrm{f}}$ parameter is calculated for the rift and $\mathrm{El} \mathrm{Golfo} \mathrm{sequences,} \mathrm{for} \mathrm{raw} \mathrm{and} \mathrm{filtered} \mathrm{data,} \mathrm{corrected} \mathrm{and}$ uncorrected for the rotation of the section. (see also Table 3).

scatter of the directions about their mean. First, it should be noted that the ratio of the precision parameters $\mathrm{Keg} / \mathrm{Kr}=3.26$ exceeds the 0.99 limiting value for an $F$ test, indicating that the scatter of the paleomagnetic directions recorded by the flows of the rift sequence is significantly larger than that of the El Golfo sequence. The value obtained for the rift and El Golfo sequences were then compared to those obtained for synthetic sequences generated using the secular variation model of Constable and Parker [27]. Time sequences were generated using the time-dependent model of Constable [28], with the correlation times of Hulot and Le Mouel [29]. The mean values for the spherical harmonic coef- 
ficients were those of Johnson and Constable [1] for the mean normal polarity field over the past 5 Ma. Each run provided 23 and 40 independent synthetic directions, to be consistent with the rift and El Golfo sequences. Also, the time frequency used for generating the synthetic sequences was $1 / 1100$ and $1 / 4500$ years, to mimic the mean extrusion rate of the rift and El Golfo sequences. In our experiments five independent drawings were made. The directional scatter about mean direction was calculated for each drawing, then the five values were averaged provide an estimate of the synthetic directional dispersion. The results are shown in Fig. 9a,b, relative to data uncorrected and corrected for the rotation respectively. The directional scatter of the rift sequence is consistent with the prediction of the model, while the value obtained for the El Golfo sequence is significantly smaller. When the rotation of the section is taken into account (Fig. 9b), the mean directions have the same zero declination as those produced by the model, and the only difference is the inclination anomaly discussed above.

The low value of the directional scatter, which is independent on whether the island has undergone a rotation or not, is in agreement with the reduced VGP scatter obtained for the El Golfo sequence, and therefore yields additional evidence for the existence of a period of low secular variation in the Canary Island region between 442 and $261 \mathrm{ka}$.

\section{Conclusions}

This paleomagnetic study of the two sequences in the island of El Hierro provides a new set of paleomagnetic directions obtained with modern laboratory methods and with precise time constraints.

The inclination anomaly and the amplitude of the secular variation for the rift sequence are consistent with published data from other areas in the same latitudinal band. On the contrary, data from the El Golfo sequence suggest that a period of low secular variation has occurred in the Canary Islands, in the interval between at least 442 and $261 \mathrm{ka}$. This evidence, documenting some non-stationarity of the paleosecular variation, should be further scrutinized in order to determine its exact duration and its geographical extent. Studies currently under way in a)

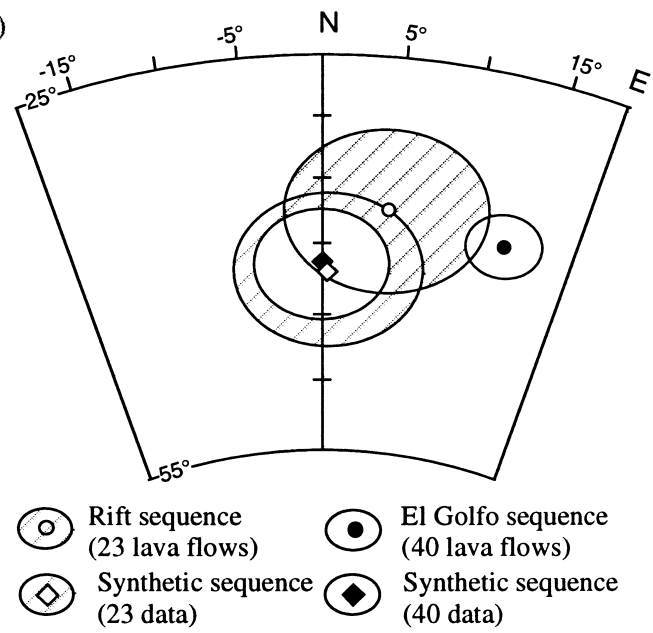

b)

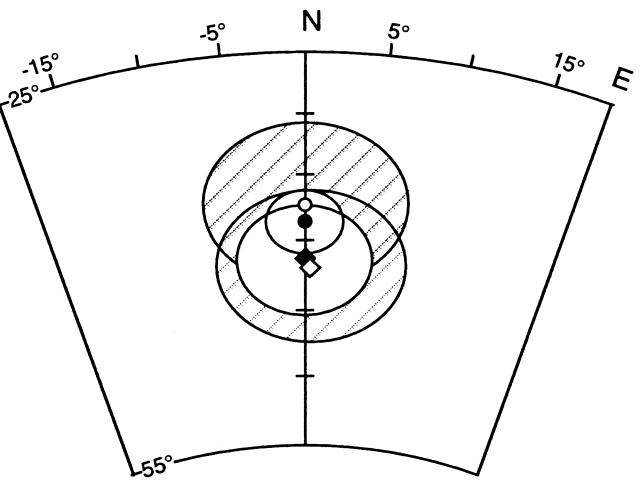

Fig. 9. Mean directions and $\alpha_{95}$ confidence ellipses calculated for synthetic sequences and for the rift and El Golfo sequences (a) uncorrected and (b) corrected for the rotation of the section. The dispersion observed for the rift sequence is consistent with the prediction of Constable and Parker model [27] while the scatter obtained for the El Golfo sequence is significantly smaller.

the nearby island of La Palma, from a section only slightly older than the El Golfo sequence will allow us to better address the first aspect.

\section{Acknowledgements}

We wish to thank Laurie Brown and Cathy Constable for their careful and constructive reviews of an early version of the manuscript. Mike Hutnak and Nick Teanby are also thanked for improving our American/English. This work was supported in 
France by the CEA and the CNRS, and in Spain by the CSIC. The authors also gratefully acknowledge financial help for the field trips by NATO Grant $\mathrm{N}^{\circ} \mathrm{CRG}$ 940609. The PhD grant for N.S. was given by the CEA. The directional determinations were done using the program 'PaleoMag' derived from the code written by Kirschvink [30] and adapted for the Macintosh by R. Ripperden and C. Jones, which can be downloaded directly from the University of Colorado www site (http://cires.colorado.edu/people/ jones.craig/). This is LSCE contribution No. 158. [RV]

\section{References}

[1] C.L. Johnson, C.G. Constable, The time-average geomagnetic field: global and regional biases for 0-5 Ma, Geophys. J. Int. 131 (1997) 643-666.

[2] Iaga News, 37, December 1997, p. 18, Resolution \#7.

[3] N.D. Watkins, A. Richardson, R.G. Mason, Paleomagnetism of the Macaronesian Insular Region: The Canary Islands, Earth Planet. Sci. Lett. 1 (1966) 225-231.

[4] J.M. Ade-Hall, N.D. Watkins, Absence of correlations between opaque petrology and natural remanence polarity in Canary Island lavas, Geophys. J. R. Astron. Soc. 19 (1970) 351-360.

[5] A. Abdel-Monem, N.D. Watkins, P.W. Gast, Potassiumargon ages, volcanic stratigraphy, and geomagnetic polarity history of the Canary Islands: Lanzarote, Fuerteventura, Gran Canaria, and La Gomera, Am. J. Sci. 271 (1971) 490-521.

[6] A. Abdel-Monem, N.D. Watkins, P.W. Gast, Potassiumargon ages, volcanic stratigraphy, and geomagnetic polarity history of the Canary Islands: Tenerife, La Palma, and Hierro, Am. J. Sci. 272 (1972) 805-825.

[7] N.D. Watkins, Paleomagnetism of the Canary Islands and Madeira, Geophys. J. R. Astron. Soc. 32 (1973) 249-267.

[8] C.L. Johnson, C.G. Constable, Paleosecular variation recorded, by lava flows over the past five million years, Philos. Trans. R. Soc. London 354 (1996) 89-141.

[9] X. Quidelleur, J.-P. Valet, Geomagnetic changes across the last reversal recorded in lava flows from La Palma, Canary Islands, J. Geophys. Res. 101 (1996) 13755-13773.

[10] H. Guillou, J.C. Carracedo, F. Perez Torado, E. Rodriguez Badiola, $\mathrm{K}-\mathrm{Ar}$ ages and magnetic stratigraphy of a hotspot-induced, fast grown oceanic island: El Hierro, Canary Islands, J. Volcanol. Geotherm. Res. 73 (1996) 141155.

[11] K. Hoernle, G. Tiltion, H.U. Schmincke, $\mathrm{Sr}-\mathrm{Nd}-\mathrm{Pb}$ isotopic evolution of Gran Canaria: evidence for shallow enriched mantle beneath the Canarian Islands, Earth Planet. Sci. Lett. 106 (1991) 44-63.

[12] J.S. Holik, P.D. Rabinowitz, J.A. Austin, Effects of Ca- nary hotspot volcanism on structure of oceanic crust off Morocco, J. Geophys. Res. 96 (B7) (1991) 12039-12067.

[13] A. Hernandez Paheco, Sobre una posible erupcion en 1793 en la isla de El Hierro (Canarias), Estud. Geol. 38 (1982) $15-25$.

[14] D. Elsworth, B. Voight, Dike intrusion as a trigger for a large earthquakes and the failure of volcano flanks, J. Geophys. Res. 100 (1995) 6005-6024.

[15] R.T. Holcomb, R.C. Searle, Large landslides from oceanic volcanoes, Mar. Geotechnol. 10 (1991) 19-32.

[16] D.G. Masson, TOBI surveys and coring of debris flows west of the Canaries, Institute of Oceanographic Sciences, Deacon Laboratory, 1994.

[17] J.C. Carracedo, The Canary Islands: an example of structural control on the growth of large oceanic-island volcanoes, J. Volcanol. Geotherm. Res. 60 (1994) 225-241.

[18] P. Cassignol, P.Y. Gillot, Range and effectiveness of unspiked potassium-argon dating: experimental groundwork and applications, in: G.S. Odin (Ed.), Numerical Dating in Stratigraphy, Wiley, Chichester, 1982, pp. 159-179.

[19] P.L. McFadden, D.L. Jones, The fold test in paleomagnetism, Geophys. J. R. Astron. Soc. 67 (1981) 53-58.

[20] E.A. Mankinen, M. Prévot, C. Sherman Grommé, R.S. Coe, The Steen Mountain (Oregon) geomagnetic polarity transition 1. Directionnal history, duration of episodes, and rock magnetism, J. Geophys. Res. 90 (1985) 10393-10416.

[21] M.W. McElhinny, P.L. McFadden, R.T. Merrill, The myth of the Pacific dipole window, Earth Planet. Sci. Lett. 143 (1996) 13-22.

[22] D. Vandamme, M. Bruneton, Problem of elimination of directional data clusters in PSV studies, in: European Geophysical Society suppl. I to vol. 16, Nice, 1998.

[23] J.J. Love, Paleomagnetic volcanic data and geomagnetic regularity of reversals and excursion, J. Geophys. Res. (1998) in press.

[24] S.J. Day, J.C. Carracedo, H. Guillou, Age and geometry of an aborted rift flank collapse: the San Andres fault system, El Hierro, Canary Island, Geol. Mag. 134 (1997) 523-537.

[25] M.W. McElhinny, P.L. McFadden, Paleosecular variation over the past 5 Myr based on a new generalized database, Geophys. J. Int. 131 (1997) 240-252.

[26] A. Cox, Confidence limits for the precision parameter K, Geophys. J. R. Astron. Soc. 18 (1969) 545-549.

[27] C. Constable, R. Parker, Statistics of the geomagnetic secular variation for the past 5 m.y., J. Geophys. Res. 93 (1988) 11569-11581.

[28] C. Constable, A simple statistic model of geomagnetic reversals, J. Geophys. Res. 95 (1990) 4587-4596.

[29] G. Hulot, J.-L. Le Mouël, A statistical approach to the Earth main magnetic field, Phys. Earth Planet. Inter. 82 (1994) 167-183.

[30] J.L. Kirschvink, The least-square line and plane and the analysis of paleomagnetic data, Geophys. J. R. Astron. Soc. 62 (1980) 699-718.

[31] R.H. Steiger, E. Jäger, Convention on the use of decay constants in geocosmochronology, Earth Planet. Sci. Lett. 36 (1977) 359-362. 